\title{
Erratum to: The Antarctic toothfish (Dissostichus mawsoni): biology, ecology, and life history in the Ross Sea region
}

\author{
Stuart Hanchet $\cdot$ Alistair Dunn • Steven Parker • \\ Peter Horn · Darren Stevens · Sophie Mormede
}

Published online: 1 October 2015

(C) Springer International Publishing Switzerland 2015

\section{Erratum to: Hydrobiologia \\ DOI 10.1007/s10750-015-2435-6}

Regrettably, the source of Fig. 1 was omitted from the caption of the above mentioned publication. The correct figure caption and the additional reference are published here and should be treated as definitive by the reader.

Fig. 1 Proportion of D. mawsoni of the total Dissostichus spp. catch by number in longline catches by $0.5^{\circ}$ longitude $\times 0.5^{\circ}$ latitude cells from CCAMLR fine scale catch and effort data. Solid lines denote CCAMLR Subareas and Divisions, and lighter grey lines indicate SSRUs (Source: SC-CAMLR-XXX, 2011)

\section{Reference}

SC-CAMLR-XXX, 2011. Report of the 30th meeting of the Scientific Committee for the Conservation of Antarctic Marine Living Resources: 454 pp.
The online version of the original article can be found under doi:10.1007/s10750-015-2435-6.

S. Hanchet $(\bowtie) \cdot S$. Parker

National Institute of Water and Atmospheric Research (NIWA) Ltd, P.O. Box 893, Nelson, New Zealand e-mail: s.hanchet@niwa.co.nz

A. Dunn · P. Horn - D. Stevens · S. Mormede National Institute of Water and Atmospheric Research (NIWA) Ltd, Private Bag 14901, Wellington,

New Zealand 